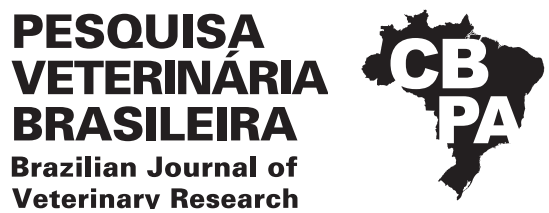

Pesq. Vet. Bras. 41:e06771, 2021

DOI: 10.1590/1678-5150-PVB-6671

Original Article

Small Animal Diseases

ISSN 0100-736X (Print)

ISSN 1678-5150 (Online)

\title{
Information technology by mobile communication for the notification of canine visceral leishmaniasis ${ }^{1}$
}

\author{
Jaíne S.P. Vasconcellos ${ }^{2 *}$ (D), Fabiana R. Ratzlaff², Fernanda S.F. Vogel² ${ }^{2}$ Enio Giotto ${ }^{3}$, \\ Heitor G.C. Veiga ${ }^{3}$, Sônia A. Botton² and Luís A. Sangioni ${ }^{2}$
}

\begin{abstract}
Vasconcellos J.S.P., Ratzlaff F.R., Vogel F.S.F., Giotto Ê., Veiga H.G.C., Botton S.A. \& Sangioni L.A. 2021. Information technology by mobile communication for the notification of canine visceral leishmaniasis. Pesquisa Veterinária Brasileira 41:e06771, 2021. Departamento de Medicina Veterinária Preventiva, Centro de Ciências Rurais, Universidade Federal de Santa Maria, Av. Roraima 1000, Camobi, Santa Maria, RS 97105-900, Brazil. E-mail: jainevasconcellos@hotmail.com

Visceral leishmaniasis is the most severe form of a human and animal disease complex entitled leishmaniasis, which is endemic to 70 countries. It is imperative to develop and offer technologies capable of increasing the resolution ability of control programs of this zoonosis. In the search for technological innovations in health, especially in environmental surveillance, the objective is to develop a mobile application (App) for smartphones in order to facilitate and systematize the notification of positive cases of canine visceral leishmaniasis (CVL) by veterinarians working in clinics for assisting the municipal health surveillance in the management of this zoonosis. Thus, we developed an App, C7 LVC - Canine Visceral Leishmaniasis Notification System, with formatting based on the CR Campeiro $7^{\circledR}$ software. The technology created enables the filling of important gaps in information systems, facilitating the transmission of data and the use of this data by public management bodies to take CVL prevention and control actions.
\end{abstract}

INDEX TERMS: Mobile communication, canine visceral leishmaniasis, Apps, smartphones, C7LVC, notification, dogs.

\begin{abstract}
RESUMO.- [Tecnologia da informação por comunicação móvel para notificação de leishmaniose visceral canina.] A leishmaniose visceral é a forma mais grave de um complexo de doenças humanas e animais, denominado leishmaniose, endêmica em 70 países. É imprescindível desenvolver e oferecer tecnologias capazes de aumentar a capacidade de resolução dos programas de controle desta zoonose. Na busca por inovações tecnológicas em saúde, principalmente na vigilância ambiental, o objetivo é desenvolver um aplicativo móvel (App) para smartphones a fim de facilitar e sistematizar a notificação de casos positivos de leishmaniose visceral canina (LVC) por médicos veterinários que atuam em clínicas auxiliando a vigilância sanitária municipal, na gestão desta zoonose. Para
\end{abstract}

\footnotetext{
${ }^{1}$ Received on March 23, 2021.

Accepted for publication on April 8, 2021.

${ }^{2}$ Departamento de Medicina Veterinária Preventiva (DMVP), Centro de Ciências Rurais (CCR), Universidade Federal de Santa Maria (UFSM), Av. Roraima 1000, Camobi, Santa Maria, RS 97105-900, Brazil. *Corresponding author: jainevasconcellos@hotmail.com

${ }^{3}$ Departamento de Engenharia Rural (DEGR), Centro de Ciências Rurais (CCR), Universidade Federal de Santa Maria (UFSM), Av. Roraima 1000, Camobi, Santa Maria, RS 970105-900, Brazil.
}

tanto, foi desenvolvido um App, C7 LVC - Sistema de Notificação da Leishmaniose Visceral Canina, com formatação baseada no software CR Campeiro $7^{\circledR}$. A tecnologia criada possibilita o preenchimento de lacunas importantes nos sistemas de informação, facilitando a transmissão de dados e a utilização desses dados pelos órgãos da gestão pública para a tomada de ações de prevenção e controle da LVC.

TERMOS DE INDEXAÇÃO: Comunicação móvel, leishmaniose visceral canina, Apps, smartphones, C7LVC, notificação, caninos.

\section{INTRODUCTION}

Leishmaniasis is a vector-borne zoonotic disease caused by several species of protozoa of the genus Leishmania. This infection has a worldwide distribution, and is considered a serious public health problem and one of the most neglected diseases in the world. These zoonoses account for about two million cases per year worldwide (WHO 2011).

Important changes in the epidemiological aspects of leishmaniasis have been observed over the last years. In Brazil, the disease occurs predominantly in rural and peri-urban 
environments; however, there has been a high incidence of visceral leishmaniasis, both in humans and animals, especially in large and medium-sized urban centers. This may be related to the vector's ability to adapt; it was found only in rural households, but later spread to residences, especially in the peripheries and neighborhoods of the Brazilian large cities, such as Teresina (Piauí), Campo Grande (Mato Grosso do Sul) and Belo Horizonte (Minas Gerais) (Brasil 2006).

Epidemiological scientific studies on health surveillance in the last two decades have developed new technologies for investigating outbreaks or monitoring health indicators, which enable the early identification of outbreaks and communicable diseases (Brabham 2008). Technological information innovation, with the use of smartphones and tablets, allows the development of fast, agile, and effective mobile communication in different sectors of society, as well as in the health sector (Ammenwerth et al. 2000). Mobile applications (Apps) have been used to subsidize improvements in health services, including scheduling appointments, diagnoses, and monitoring patients (Oehler et al. 2010).

Brazil, despite being internationally recognized as a computational reference pole in the field of health, for its health information systems, presents underwhelming results in scientific production related to the development of mobile information and communication technologies (ICT) aimed at this sector. The notification of diseases with clinical characteristics, which refers to rapid detection, are not covered by this type of communication, as there is a need for studies aimed at diseases that require compulsory notification (Leal-neto et al. 2016).

The Brazilian "Sistema Único de Saúde" (SUS) has been structuring the municipal management for the development of control actions, including activities related to zoonoses, vectors, reservoirs, and especially in the active search for cases of human (VL) and canine visceral leishmaniasis (CVL). These procedures, including epidemiological surveillance activities and the control of VL, have been assigned to municipalities (Brasil 2006).

In the current flow of information related to VL, with respect to health surveillance, especially epidemiological and environmental surveillance, a sick individual may be notified through the official networks only after the diagnosis of the infection. However, the interval between illness and notification of the disease may have an impact on public health if the infected patient is exposed to the vectors, allowing the transmission of the agent to other individuals, both humans and animals (Christakis \& Fowler 2010, Wójcik et al. 2014).

One of the objectives of the VL control program linked to SUS, in the context of individual health, is to include the states and municipalities with silent outbreaks, that is, to identify the locations where there are no notifications of the occurrence of the disease in humans or animals. In these locations, surveillance and control actions should be initiated, aiming to avoid or minimize the occurrence of new cases (Brasil 2014).

Activities related to the identification of VL outbreaks include data recording, procedures for the identification of positive cases, blood collection for serological tests, planning and treatment strategies, and epidemiological studies. These measures require time, structure, and human resources to carry out the proposed programs. The use of ICT, such as mobile devices, can streamline and complement these activities, in a clear, efficient and effective way (Mosa et al. 2012, Souza et al. 2013). Apps are considered as a set of technologies developed to perform specific tasks and jobs (Banos et al. 2015).

To control VL, as proposed by the Ministry of Health, it is necessary to spatially analyze the occurrence of the disease in the main reservoirs, such as dogs, as well as in the human population, and determine the vector distribution in the municipalities where it occurs. Spatial location technologies, such as georeferencing, have shown great potential in supporting decision-making in the field of health. Knowledge of the location of epidemiological phenomena increases the possibilities for better planning and the generation of theoretical bases on the occurrence of such phenomena. Thus, it would be possible to monitor the disease as well as execute essential sanitary measures to contain its spread more quickly and effectively (Amorim et al. 2013).

Several electronic platforms, such as HealthMap, Google Flu Trends, and Flu Near You, allow the visualization of epidemiological scenarios around the world, providing data on diseases for the population, travelers and health services (Leal-Neto et al. 2016). Brazil has successful experience in the use of data extraction from social networks and participatory surveillance linked to the study of dengue epidemiology, including projects such as the "Dengue Observatory" and "Dengue on the Web" (Wójcik et al. 2014). Both instruments use websites as interaction platforms and are aimed at the spatialization of information. In addition to these, the country has generated important results using the platforms "Saúde na Copa," created in 2014 due to Soccer World Cup, and "Guardiões da Saúde," created in 2016 due to Olympic Games, both of which use websites and Apps (Leal-Neto et al. 2016).

One of the steps for the incorporation of health technologies in Brazil by SUS, according to Brasil (2016), is the submission of proposals for technological innovation to the National Commission for the Incorporation of Technologies in SUS. This committee assesses the development of information tools, based on effectiveness, costs and budgetary impact, beneficiary population, social impact, ethical issues, acceptability, and logistics and sustainability, among others. Thus, the purpose of this research is to report the development of an App that allows the notification of new cases of CVL by veterinarians. Our research team sought to create an instrument capable of supporting epidemiological studies, including the territorial spatialization of the CVL and the transfer of data to public managers, for later availability to SUS.

\section{MATERIALS AND METHODS}

This study was carried out in partnership with "Universidade Federal de Santa Maria" (UFSM) and the Municipality of Santa Maria, Superintendence of Health Surveillance. Systematic meetings were held to investigate the demands of Environmental Surveillance services in the control and prophylaxis of CVL, in order to identify the demands of this service, as well as collaborate in the structuring of coping with this problem. Using the notification forms that are currently used by information systems for VL and the environmental and epidemiological surveillance agencies of the municipalities of the federation, information that is considered essential for the notification of the disease and the design of studies of the epidemiology of CVL was recorded. This information included identification data of the owner and/or the person responsible for the referral, data related to the animal (sex, race, age, and coat, among other characteristics, as well as the clinical condition and laboratory data), and data of a 
general nature, such as identification of the person in charge of the service, among other information. This set of elements was used to construct the interface of the App.

In the search for patent bases, the records in PATENTSCOPE, Espacenet, and the National Institute of Industrial Property were consulted, using the following keywords: Visceral Canine Leishmaniose System, C7 LVC, LVC app. In this search, it was found that there was no other App with identical or similar characteristics.

The development and formatting of the App was based on the CR Campeiro $7^{\circledR}$ software. The App was named C7 LVC - Canine Visceral Leishmaniasis Notification System; it will be tested in the municipality of Santa Maria, Rio Grande do Sul (RS), in a pilot study, but with possibilities for its expansion and applicability throughout the National territory.

To develop the C7 LVC App, the Eclipse tool in the Java language, and the Android development package, which has a free license for developers, were used; both were available free of charge on the Internet. The database management system (DB) employed in this phase was PostgreSQL for the version of the DB on the desktop and for the release of data from the Android App to the server. To develop the DB, the programming language, Structured Query Language (SQL), was used.

The DB comprised information filled out by the users of the App, based on information on dogs diagnosed with CVL. Subsequently, these data were deposited into a central server.

After the final tests, the App will be made available on the Play Store for Android, for user download. Access will be granted upon filling out a registration that will be managed by the creator team of the system. Access to the DB with all the information will be restricted to the municipal health management agency.

\section{RESULTS}

The basic functionalities of the App include: a) a photographic record of the animal and copies of exams and reports; b) a personalized report of each case, which, upon filling out, will generate a document in PDF format; c) transmission of the CVL notification data completed by the user (veterinarian registered in the App's management system) to the administrator server, where they can later be accessed in the investigation process by the health service registered in the App's management system; d) communication of the notification form generated as a PDF file by e-mail to registered users and health services previously registered in the system; and e) spatial visualization of the location of the diagnosed cases.

The current interface of the App allows access to the functionalities (Fig.1) offered by the initial menu. When accessing the "Enter" button, the user of the App (veterinary medical professional) will find the initial menu (Fig.2) that will allow access to the registration of notifications under the "LVC Notifications" button. In addition, it is possible to view the buttons "Edit notification," "Photographic records," "Send notification," "Reports," "Spatialization," "Info-application," and "Exit."

When accessing the "LVC Notification" button, the user will be able to fill in data referring to the owner (Fig.3), which include name, address, municipality, state, telephone, e-mail, and the date of the notification, and proceed by clicking the "Save" button. Then, the user will receive information that they can proceed with the registration of the animal's identification by selecting the "Animal ID" button.

Upon clicking on the "Animal ID" button, the user will be asked to fill in data related to the animal (Fig.4): name, breed, coat/color, sex, age, type of domicile, and pet number microchip. The items "breed" and "coat" have a previous listing of the most common presentations found in dogs, to facilitate and speed up the filling out of the notification by the user.

Then, the user can choose the "Back" button, which will allow information to be edited at another time, or the "Clinical Condition" button to include the animal's clinical data (Fig.5). In this menu, the user must fill in the date of the dog's attendance, followed by a list of previously listed clinical signs: peeling, skin ulcer, onychogryphosis, keratoconjunctivitis, runny nose, apathy, weight loss, diarrhea, intestinal bleeding, vomiting, and enlarged lymph nodes. In addition to these signs, there is also the option "Others; which are?," which allows for the inclusion of signals that are not pre-listed. Thus, the veterinarian or related professional will fill, next to each clinical sign, the following options: " $0=$ does not inform," if there is no evidence of the presence of a clinical sign in the animal, " 1 = yes," if the clinical sign is present, and " $2=$ no," in the absence of the signal.

Upon filling out the notification using the App, the user will be able to click on the "Laboratory data" button. In this menu (Fig.6), collections of materials for exams will be informed: lymph node aspiration, bone marrow aspiration, liver necropsy

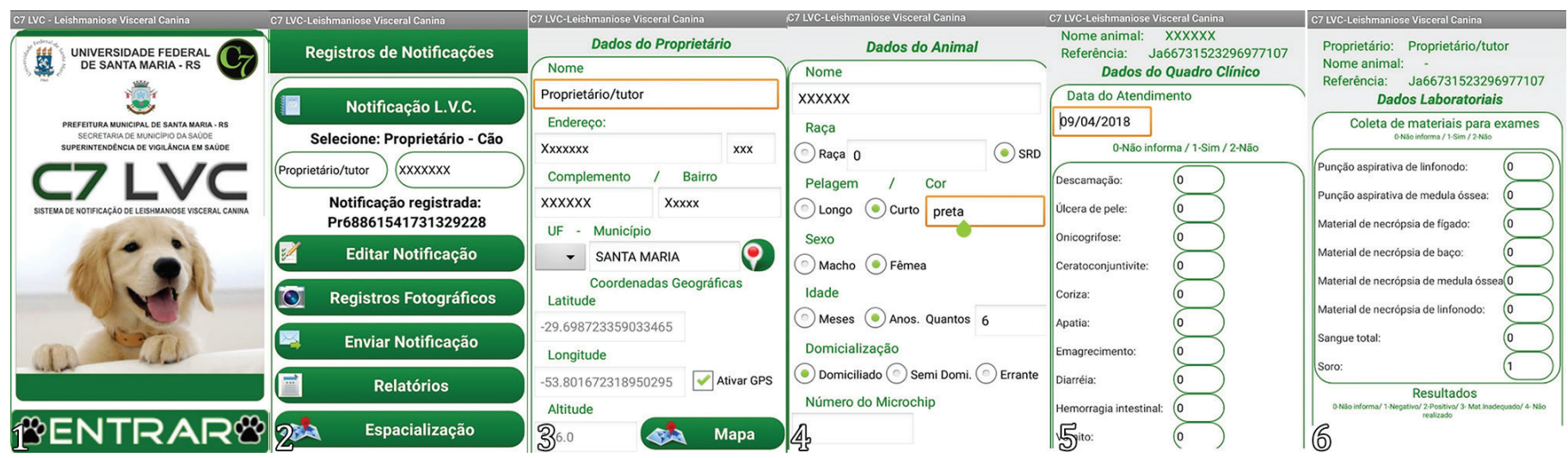

Fig.1-6. (1) App access screen seen on the user's smartphone. Initial interface of the C7 LVC App. (2) App's home menu. (3) Interface for filling in and/or accessing changes and records of owner data. (4) Interface for filling in and/or accessing animal data. (5) App interface for filling out clinical data. (6) App interface for filling in Laboratory Data. 
material, spleen necropsy material, bone marrow necropsy material, lymph necropsy material, whole blood, and serum. The options for filling in this information are the numbers 0 , 1 , and 2 , as mentioned above.

Moreover, in the "Laboratory data" menu, the user can fill in information about the type of test performed (rapid test, indirect immunofluorescence - IIF, fine-needle aspiration cytology - FNAC, enzyme-linked immunosorbent assay - ELISA, and polymerase chain reaction - PCR) and the results obtained in the exams carried out by the veterinarian.

Then, the "General data" or "Back" buttons can be activated. Upon clicking "General data," a menu will open (Fig.7) to allow the recording of information regarding the death of the animal, when applicable; the cause of death must be filled in, as follows: natural, euthanasia, other, or without information. If the animal is alive, the veterinarian must inform whether he has opted for the following procedures: animal collaring, treatment, environmental management, and/or euthanasia. In this menu, more than one option can be chosen.

In this same menu, other observations can be filled out, referring to the name of the professional responsible for the notification and their enrollment in a professional organization of veterinary medicine, in addition to their contact information. Once the notification is filled out, the system will direct the user to the home menu. In this interface, the following options can be selected: "Photographic records," "Send notification," "Spatialization," and "Report."

Upon typing the address of the owner, the App allows georeferencing, which is performed by the smartphone's Global Positioning System (GPS) (Fig.8 and 9). Thus, latitude and longitude information are imported, delimiting the location of the notified case.

The health services that will receive the notifications will have access to the DB with the information related to their municipality of responsibility. This database allows the visualization of data in tables that can be exported to other programs for statistical analysis.

\section{DISCUSSION}

According to a study carried out by the "Fundação Getúlio Vargas", São Paulo (FGV-SP), released in April 2018, Brazil had 306 million portable devices in use, including smartphones, notebooks, and tablets (Meirelles 2018). The adoption rate of these mobile devices by health professionals varies between $45 \%$ and $85 \%$ worldwide, making the technologies aimed at these professionals popular (Garritty \& El Eman 2006). The ICT used in the healthcare field are considered a global resource that connects users through several digital resources, which organize an information network that allows the development and improvement of professionals in this segment (Guimarães \& Godoy 2012). ICT employ different tools that support the structuring and organization of information, and enable storage, processing, real-time or remote access, and data sharing between professionals and users (Guimarães \& Godoy 2012, Matsuda et al. 2015).

The strategies recommended by official agencies for the control of CVL have limitations, such as logistical problems for the elimination of positive dogs, related to the time of diagnosis for decision-making with regard to euthanasia (Courtenay et al. 2002); low quality, specificity, and sensitivity of the tests used in the diagnosis (Romero \& Boelaert 2010, Courtenay et al. 2002); immediate replacement of dogs by the population, expanding the potential reservoirs in the locality of the disease (Andrade et al. 2007, Nunes et al. 2008); and discontinuation of interventions for infection control (Malaquias et al. 2007, Barata et al. 2013). All these factors lead to the failure of VL control programs; hence, there is a growing need to develop innovative technologies that promote programs in the health field.

Leishmaniasis is a notifiable disease (Brasil 2020). For this purpose, the Brazilian Ministry of Health has a notification system that uses forms that are filled out manually by health professionals. The data are subsequently recorded in a public access disease notification system (SINAN ${ }^{1}$ ) (Brasil 2006, 2014). In the case of CVL, there is no standard form for such

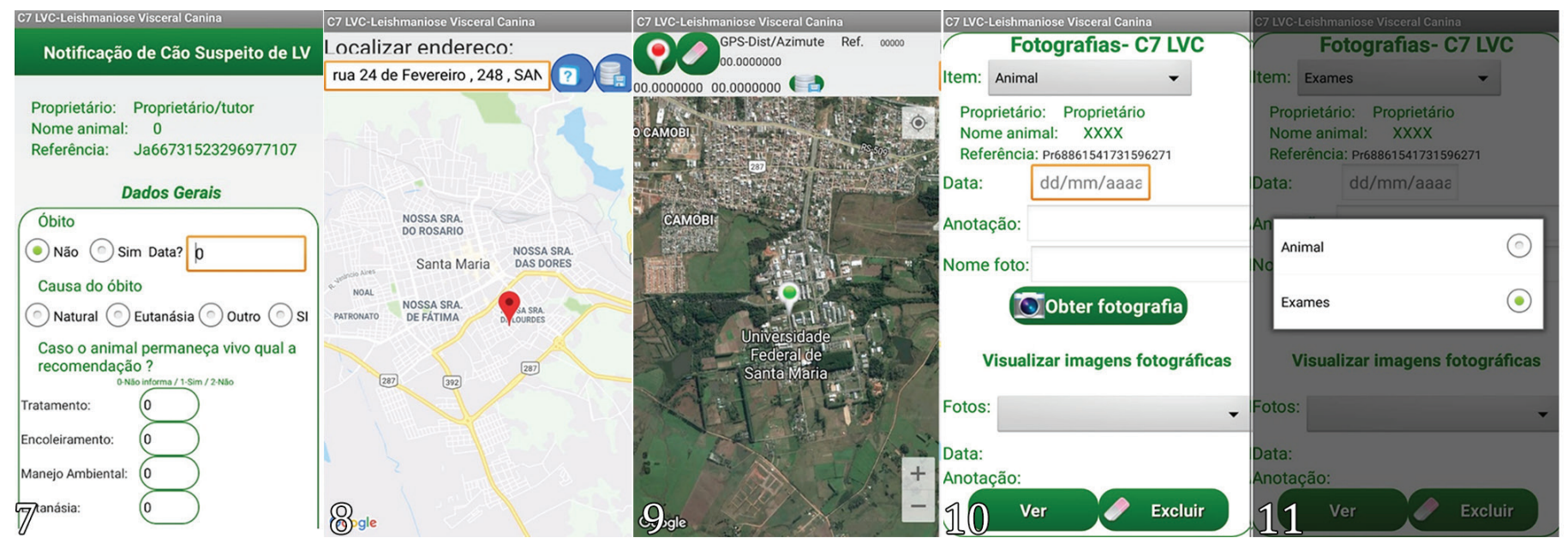

Fig.7-11. (7) App interface for filling in general data. (8-9) App interface for spatial visualization of cases: (8) access to the map by geographic coordinates, $(\mathbf{9})$ geospatialization by address. (10-11) App interface for accessing data: (10) registration and registration of new photographs, (11) photographic record option of laboratory or animal reports.

${ }_{1}$ Available at <http://sinan.saude.gov.br/sinan/login/login.js> 
notifications that allow the creation of a DB of information and subsequently the triggering of surveillance actions in Brazil. However, to achieve the objectives established by the VL control program, it is necessary to monitor the trend of the disease, considering its distribution in time and space (Brasil 2014).

Epidemiological studies on health surveillance in the past two decades have aimed to recruit new methodologies for investigating outbreaks or monitoring trends in infectious diseases, seeking to anticipate these public health events as accurately as possible (Brabham 2008). To this end, owing to C7 LVC, health services at the municipal level will have access to data related to notifications, which will be stored in a DB. Using these notifications, they will be able to define a flow for the information, as well as take pertinent health actions consistent with the epidemiological reality of the region.

In a systematic review study involving the use of mobile tools, the authors listed the main characteristics that support the use of mobile applications in the context of health, among which are: accessibility, mobility, low cost for the user, capacity, continuous data transmission, geolocation of cases, and multimedia capability (Free et al. 2010). The C7 LVC App uses tools available on smartphone devices, such as GPS, and presents the most important quality characteristics for software, such as functionality, reliability, usability, efficiency, maintainability, and portability, as indicated by the "Associação Brasileira de Normas Técnicas" (ABNT 2003).

The App's interface allows the expansion of data transmission and reporting in order to streamline the CVL diagnostic notification and confirmation process. The App also offers the option of photographic registration of the notified animal and allows the sending of laboratory exam reports (Fig.10 and 11). Such features allow the maintenance of information of great relevance in the $\mathrm{DB}$, which will assist in the epidemiological study of the locality and contribute to the planning of health. Therefore, a dynamic process will require a permanently active information system, with updated monitoring (Soares et al. 2017). As the C7 LVC is able to access important functions such as the georeferencing of new cases, efficiently and continuously, as well as the production of maps that can be viewed on the App by professionals. This feature will allow the visualization of the disease in a territory. Consequently, more effective and efficient action measures can be defined by competent health agencies. Recent studies have concluded that the new ICT make it possible to disseminate and update knowledge in the health field (Guimarães \& Godoy 2012, Matsuda et al. 2015, Barra et al. 2016). At the same time, these technologies can support decision making and contribute to the elaboration of contingency plans for VL.

\section{CONCLUSIONS}

C7 LVC seems to be the first App developed for use by veterinary medical professionals associated with the Brazilian "Serviço Único de Saúde" (SUS).

This new mobile information and communication technologies (ICT) aims to help control canine visceral leishmaniasis (CVL), as well as improve health services linked to SUS. It allows important gaps in information systems to be filled, facilitating the transmission of data and the use of such data by public management agencies for taking actions in order to prevent and control of CVL.
Acknowledgments.- The authors are grateful to the "Coordenação de Aperfeiçoamento de Pessoal de Nível Superior" (CAPES), Brazil, and "Conselho Nacional de Desenvolvimento Científico e Tecnológico" (CNPq), for their financial support.

Conflict of interest statement.- The authors declare that there is no conflict of interest.

\section{REFERENCES}

ABNT 2003. Engenharia de Software - Qualidade de Produto. NBR ISO/IEC 9126-1, Associação Brasileira De Normas Técnicas, Brasil. 21p. Available at <https://jkolb.com.br/wp-content/uploads/2014/02/NBR-ISO_IEC9126-1.pdf> Accessed on Mar. 1, 2021.

Ammenwerth E., Buchauer A., Bludau B. \& Haux R. 2000. Mobile information and communication tools in the hospital. Int. J. Med. Inform. 57(1):21-40. <https://dx.doi.org/10.1016/S1386-5056(99)00056-8><PMid:10708253>

Amorim N.C., Ribeiro D.L., Santos G.C., Moreira V.S. \& Lopes A.B. 2013.0 uso de Geotecnologias aplicado à área da saúde: análise espacial da ocorrência de leishmaniose visceral em Itaqui RS. Anais do 5ํㅗão Internacional de Ensino, Pesquisa e Extensão da Unipampa: salão de pesquisa 5(2).

Andrade A.M., Queiroz L.H., Nunes G.R., Perri S.H.V. \& Nunes C.M. 2007. Dog replacement in an area endemic for visceral leishmaniasis. Revta Soc. Bras. Med. Trop. 40(5):594-595. <https://dx.doi.org/10.1590/S003786822007000500021><PMid:17992421>

Banos O., Villalonga C., Garcia R., Saez A., Damas M., Holgado-Terriza J.A., Lee S., Pomares H. \& Rojas I. 2015. Design, implementation and validation of a novel open framework for agile development of mobile health applications. Biomed. Eng. Online. 14(Supl.2):S6. <https://dx.doi.org/10.1186/1475 925X-14-S2-S6><PMid:26329639>

Barata R.A., Peixoto J.C., Tanure A., Gomes M.E., Apolinário E.C., Bodevan E.C., Araújo H.S., Dias E.S. \& Pinheiro A.C. 2013. Epidemiology of visceral leishmaniasis in a reemerging focus of intense transmission in Minas Gerais State, Brazil. Biomed Res. Int. 2013:405083. <https://dx.doi. org/10.1155/2013/405083><PMid:24000322>

Barra D.C.C., Almeida S.R.W., Sasso G.T.M.D., Paese F. \& Rios G.C. 2016 Metodologia para modelagem e estruturação do processo de enfermagem informatizado em terapia intensiva. Texto Contexto Enferm. 25(3):e2380015. <https://dx.doi.org/10.1590/0104-07072016002380015>

Brabham D.C. 2008. Crowdsourcing as a model for problem solving: an introduction and cases. Convergence 14(1):75-90. <https://dx.doi. org $/ 10.1177 / 1354856507084420>$

Brasil 2006. Manual de Vigilância e Controle da Leishmaniose Visceral Normas Técnicas. Secretaria de Vigilância em Saúde, Departamento de Vigilância Epidemiológica, Ministério da Saúde, Brasília, DF. 120p. Available at <https://bvsms.saude.gov.br/bvs/publicacoes/manual_vigilancia_ controle_leishmaniose_visceral.pdf> Accessed on Jan. 15, 2021.

Brasil 2014. Manual de Vigilância e Controle de Leishmaniose Visceral. Secretaria de Vigilância em Saúde, Departamento de Vigilância Epidemiológica, Ministério da Saúde, Brasília, DF. 120p. Available at <https://bvsms.saude.gov.br/bvs/ publicacoes/manual_vigilancia_controle_leishmaniose_visceral_1edicao. pdf> Accessed on Mar. 1, 2021.

Brasil 2016. Entendendo a Incorporação de Tecnologias em Saúde no SUS como se envolver. Ministério da Saúde, Secretaria de Ciência, Tecnologia e Insumos Estratégicos, Departamento de Gestão e Incorporação de Tecnologias em Saúde, Brasília, DF. 34p. Avaliable at <http://bvsms.saude.gov.br/bvs/ publicacoes/entendendo_incorporacao_tecnologias_sus_envolver.pdf.> Accessed on Mar. 20, 2021.

Brasil 2020. Revoga a Portaria no 264, de 17 de fevereiro de 2020, e altera a Portaria de Consolidação no 4 /GM/MS, de 28 de setembro de 2017 , para incluir a doença de Chagas crônica, na Lista Nacional de Notificação Compulsória de doenças, agravos e eventos de saúde pública nos serviços de saúde públicos e privados em todo o território nacional. Portaria no 
1.061, de 18 de maio de 2020, Diário Oficial da República Federativa do Brasil, Seção 1, Ministério da Saúde, Brasília, DF. 229p.

Christakis N.A. \& Fowler J.H. 2010. Social network sensors for early detection of contagious outbreaks. PloS One 5(9):e12948. <https://dx.doi.org/10.1371/ journal.pone.0012948><PMid:20856792>

Courtenay 0., Quinnell R.J., Garcez L.M., Shaw J.J. \& Dye C. 2002. Infectiousness in a cohort of Brazilian dogs: why culling fails to control visceral leishmaniasis in areas of high transmission. J. Infect. Dis. 186(9):1314-1320. <https:// dx.doi.org/10.1086/344312><PMid:12402201>

Free C., Phillips G., Felix L., Galli L., Patel V. \& Edwards P. 2010. The effectiveness of M-health technologies for improving health and health services: a systematic review protocol. BMC Res. Notes 3:250. <https://dx.doi. org/10.1186/1756-0500-3-250> <PMid:20925916>

Garritty C. \& El Eman K. 2006. Who's using PDAs? Estimates of PDA use by health care providers: a systematic review of surveys. J. Med. Internet Res. 8(2):e7. <https://dx.doi.org/10.2196/jmir.8.2.e7> <PMid:16867970>

Guimarães E.M.P. \& Godoy S.C.B. 2012. Telenfermagem: recurso para assistência e educação em enfermagem. Revta Min. Enferm. 16(2):157-158.

Leal-Neto O.B., Dimech G.S., Libel M., Oliveira W. \& Ferreira J.P. 2016. Detecção digital de doenças e vigilância participativa: panorama e perspectivas para o Brasil. Revta Saúde Públ. 50(17):1-5. <https://dx.doi.org/10.1590/ S1518-8787.2016050006201>

Malaquias L.C.C., Romualdo R.C., Anjos Jr J.B., Giunchetti R.C., Corrêa-Oliveira R. \& Reis A.B. 2007. Serological screening confirms the re-emergence of canine leishmaniosis in urban and rural areas in Governador Valadares, Vale do Rio Doce, Minas Gerais, Brazil. Parasitol. Res. 100(2):233-239. <https://dx.doi.org/10.1007/s00436-006-0259-z> <PMid:16941189>

Matsuda L.M., Évora Y.D.M., Higarashi I.H., Gabriel C.S. \& Inoue K.C. 2015. Informática em enfermagem: desvelando o uso do computador por enfermeiros. Texto Contexto Enferm. 24(1):178-186. <https://dx.doi org/10.1590/0104-07072015002760013>
Meirelles F.S. 2018. 29ạ Pesquisa Anual de Administração e Uso de Tecnologia da Informação nas Empresas. Fundação Getúlio Vargas de São Paulo (FGVSP), São Paulo. 24p. Available at <https://eaesp.fgv.br/sites/eaesp.fgv.br/ files/pesti2018gvciappt.pdf> Accessed on Mar. 1, 2021.

Mosa A.S.M., Yoo I. \& Sheets L. 2012. A systematic review of healthcare applications for smartphones. BMC Med. Informat. Decision Making 12:67. <https://dx.doi.org/10.1186/1472-6947-12-67><PMid:22781312>

Nunes C.M., Lima V.M.F., Paula H.B., Perri S.H.V., Andrade A.M., Dias F.E.F. \& Burattini M.N. 2008. Dog culling and replacement in an area endemic for visceral leishmaniasis in Brazil. Vet. Parasitol. 153(1/2):19-23. <https:// dx.doi.org/10.1016/j.vetpar.2008.01.005><PMid:18314275>

Oehler R.L., Smith K. \& Toney J.F. 2010. Infectious diseases resources for the iPhone. Clin. Infect. Dis. 50(9):1268-1274. <https://dx.doi. org/10.1086/651602><PMid:20233061>

Romero G.A.S. \& Boelaert M. 2010. Control of visceral leishmaniasis in Latin America - a systematic review. PLoS Negl. Trop. Dis. 4(1):e584. <https:// dx.doi.org/10.1371/journal.pntd.0000584 > <PMid:20098726>

Soares V.B., Almeida A.S., Sabroza P.C. \& Vargas W.P. 2017. Vigilância epidemiológica da leishmaniose tegumentar: análise territorial local. Revta Saúde Públ. 51:1-11. <https://dx.doi.org/10.1590/S1518-8787.2017051006614>

Souza R.C., Alves L.A.C., Haddad A.E., Macedo M.C.S. \& Ciamponi A.L. 2013. Processo de criação de um aplicativo móvel na área de odontologia para pacientes com necessidades especiais. Revta ABENO 13(2):58-61. <https:// dx.doi.org/10.30979/rev.abeno.v13i2.104>

WHO 2011. Control of the leishmaniasis: report of a meeting of the WHO Expert Committee on the Control of Leishmaniasis. World Health Organization, Geneva. 186p.

Wójcik O.P., Brownstein J.S., Chunar R. \& Johansson M.A. 2014. Public health for the people: participatory infectious disease surveillance in the digital age. Emerg. Themes Epidemiol. 11:7. <https://dx.doi.org/10.1186/17427622-11-7><PMid:24991229> 